\title{
Koyunbaba Ancient Stone Quarry Dock
}

\section{Oktay Dumankaya ${ }^{1^{*}}$}

${ }^{1}$ Selçuk University, Faculty of Letters, Department of Archaeology, 42031, Konya-TR

\begin{abstract}
The subject matter of this article is the ancient stone quarry dock located in Quarter of Koyunbaba, municipality of Gümüşlük, district of Bodrum and province of Muğla. Rocks in Koyunbaba Ancient Stone Quarry are formed as a product of active volcanism in Mid-Upper Miocene. These rocks are easily shaped and also have beautiful appearances due to its green color. Thanks to this characteristic, block stones taken from this quarry are encountered in almost all the ancient settlements located in the coastal line along Halikarnassos Mausolleion and Bodrum Peninsula, particularly in Myndos Ancient City its close surrounding. When considering the size of stone quarry, it is seen that stones have been extracted from this quarry for long years. In the research we have carried out on this dock, mooring holes, bollards and ( 2 pieces of) sarcophagus made of Koyunbaba rock in the depth of 4 meters on the southern end of the dock are determined.
\end{abstract}

Keywords: Bodrum Peninsula, Koyunbaba Ancient Stone Quarry, Ancient Dock.

\section{Location}

Koyunbaba Ancient Stone Quarry dock is located in the very front of the stone quarry with the same name in Koyunbaba quarter, municipality of Gümüşlük, district of Bodrum and province of Muğla (Fig. 1-2). (Exact coordinates of the ancient dock: $37^{\circ} 44^{\prime} 51.39^{\prime \prime} \mathrm{N}$ latitude, $27^{\circ} 14^{\prime} 60.00^{\prime \prime} \mathrm{E}$ longitude). This dock might have been constructed for the purposes of transporting the block stones extracted from the ancient stone quarry located on the main land to ancient settlements on Bodrum Peninsula. The rocks in Koyunbaba Ancient Stone Quarry (Exact coordinates of ancient stone quarry: $37^{\circ}$

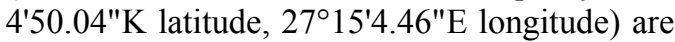
formed as a product of active volcanism in Mid-Upper Miocene (Ercan et al. 1981: 26).

\section{Determinations}

These rocks obtained from the stone quarry are easily shaped and also have beautiful appearances due to its green color. When considering the size of stone quarry, it is seen that stones have been extracted from this quarry for long years (Fig. 3).
The said dock consists of a flat ground made with shaving of the main rock. The location of the dock field consists of yellow bronze, thin, smooth sandstone, marl-clay stone layer intercalations similar to Koyunbaba ancient stone quarry (Ercan et al. 1981: 26).

The stone blocks indicating that the obtained block stones were taken away to other places in order to be used while the dock space is created, and the plank slots providing the removal of this stone blocks can be clearly seen (Fig. 2). There are many examples made with shaving of the main rock similar to the Ancient Stone Quarry Dock of Koyunbaba in harbour cities in ancient times. Commercial Harbour Docks in The Ancient City of Knidos (Büyüközer 2012: 61 ff., Plt. 24, Fig. 1-2; Plt. 25, Fig. 1-2; Plt. 26, Fig. 1-2), Dolichiste Harbour Dock (Tersane Koyu Harbour) and Teimiusa Harbour Dock in Kekova Harbour Cities (Aslan 2010: 181 ff.; 2011: 80, Plt. 82, Fig. 1-2-3), some docks the harbour of Sidon and Tyre Ancient Cities (Blackman 1982a: 92; 1982b: 196-204), some docks in Giannutri Archipelago (Archipelago Toscano) on the continental shelf of Italy (Bruno 1973: 366-367, 
Fig. 3), Ognina Harbour Dock in Sicily (Syracuse) (Frost 1973: 75 ff.; Raban, 2009:
65) can be shown as an example for such structures.

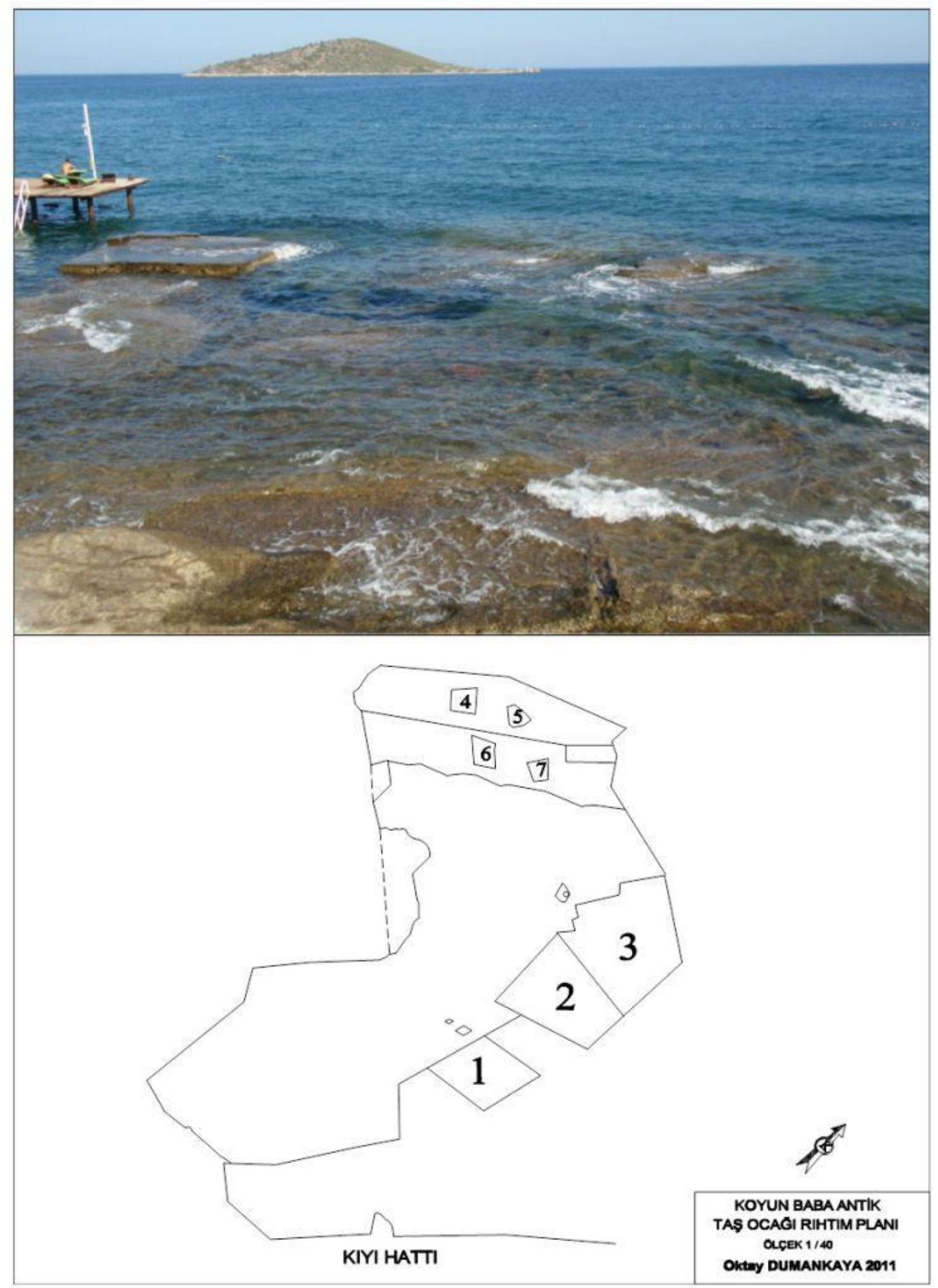

Fig 1. Koyunbaba Ancient Stone Quarry Dock's Plan and View. 
The length of this dock is 44 meters, whereas its width is 19 meters. It is seen that the western and southern parts of the dock are trimmed in a way to be aligned so that the ships can approach easily (Fig. 4-5). Furthermore, the mooring holes on the western face and bollards indicate that western and southern facets are the places for the ships to approach (Fig. 6-7).

This dock is observed to decrease $0.30 \mathrm{~cm}$ below the sea level due to high tide from time to time. (Koyunbaba Ancient Quarry Dock is in open position against Mistral, Shore wind and Southwest, which are effective in the Aegean Region. Observed that 1 meter high waves occur at the coastal line especially in the afternoons in the months we research from June to September and because of these waves the dock is under water from time to time).

This situation indicates that the dock is affected from the tectonic movements brought by the earthquakes in similar way to other ancient harbour structures located along the coastal line of Bodrum Peninsula. In the measurements

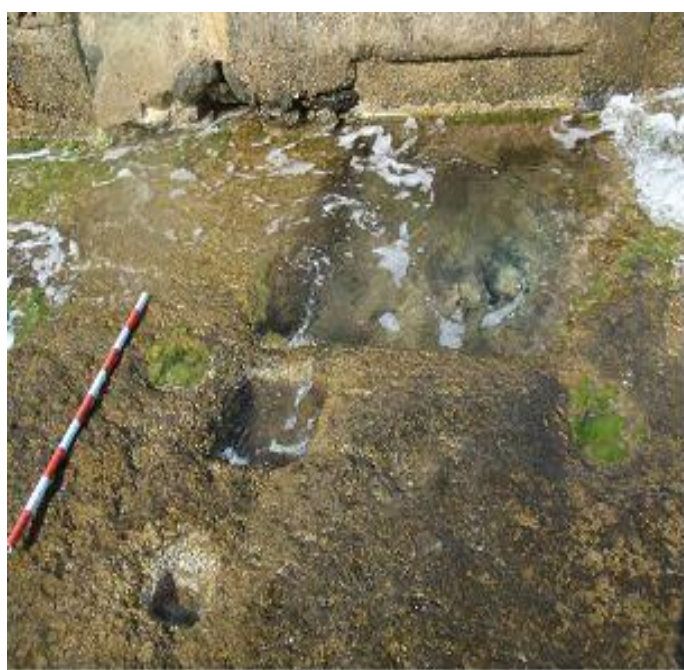

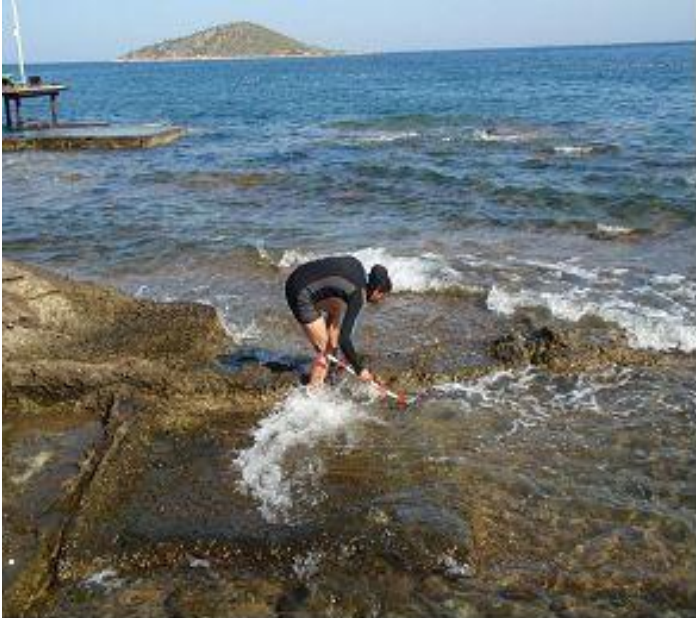

Fig 2. View of Dock Detail, Stone Block and Plank Slots.

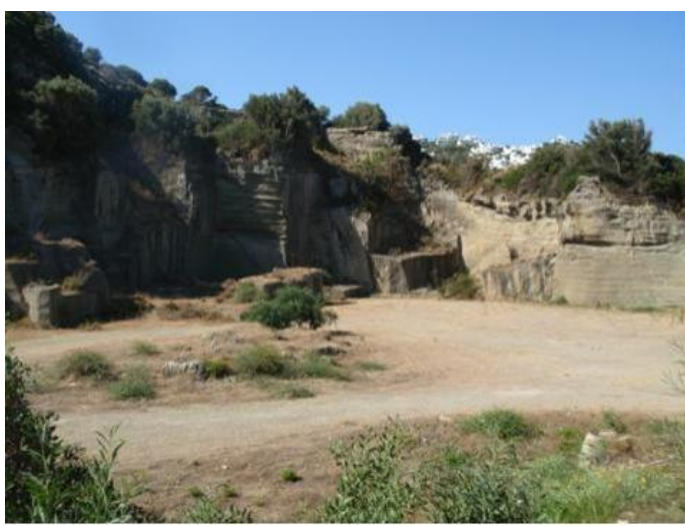

Fig. 3. General View of Koyunbaba Ancient Stone Quarry

made in an area of approximately $1500 \mathrm{~km}$ ranging from Greek Peninsula to Lebanon, which is named as 'Early Byzantium Tectonic Paroxysm', some coastal lines have increased between 0.5 and 1.0 meters mostly (Kelletat 1991: 181 ff.; Bekaroğlu 2008: 4). 


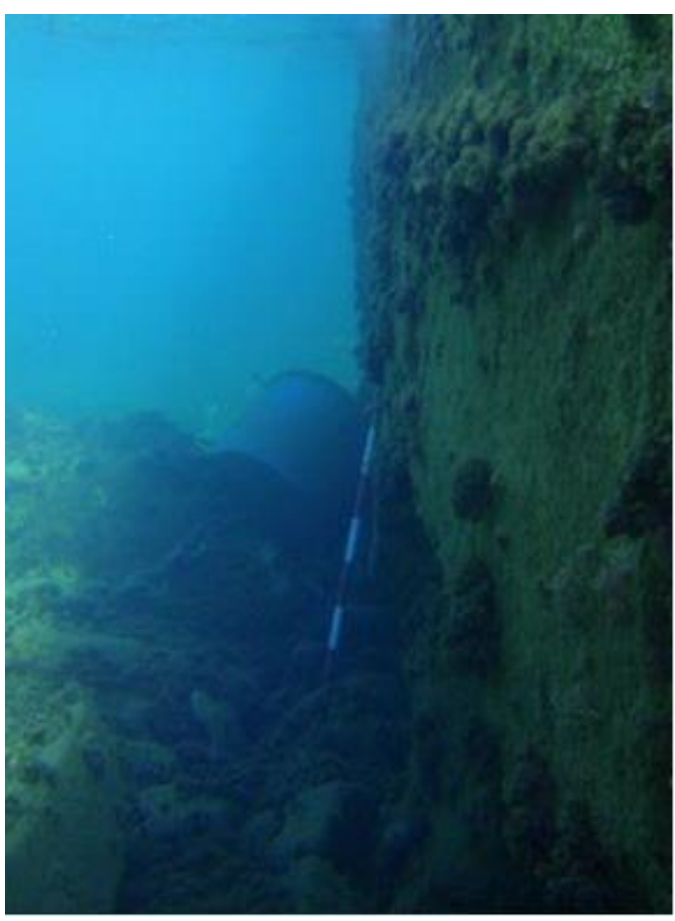

Fig 4. Southern Facet

In the researches made on harbours of Ancient Ear in Mediterranean and Aegean Regions, it is observed that the docks and the harbours, which are closed to and protected against the wind, are at least 1 meter above the sea level. (Testaguzza 1970: 166; Williams 1976, 7-78; Flemming 1978, 417-419; Blackman 1982a, Fig. 2; 1982b, 203; 2008, 648; Aslan 2010: 181 ff.; 2011: 28 ff.; Büyüközer 2012: 60). During the time interval starting from Classical term to our days, as a result of the earthquakes, height loss of 1-5 meters is seen on the dock. (Many more major earthquakes such as $222,185,155,199$ $198 \mathrm{BC}, 142,198,227,344,474,515,554$, 1304, 1481, 1843, 1856, 1863 AD earthquakes occurring in the Island of Rhodes, 334, 412, $760 \mathrm{AD}$ earthquakes occurring in the island of Kos, $365 \mathrm{AD}$ earthquake, occurring in the island of Crete, 460 AD Earthquake in Knidos have been effective in and around the Gulf of Gökova and Bodrum Peninsula. Guidoboni et al. 1994: $501 \mathrm{ff}$.

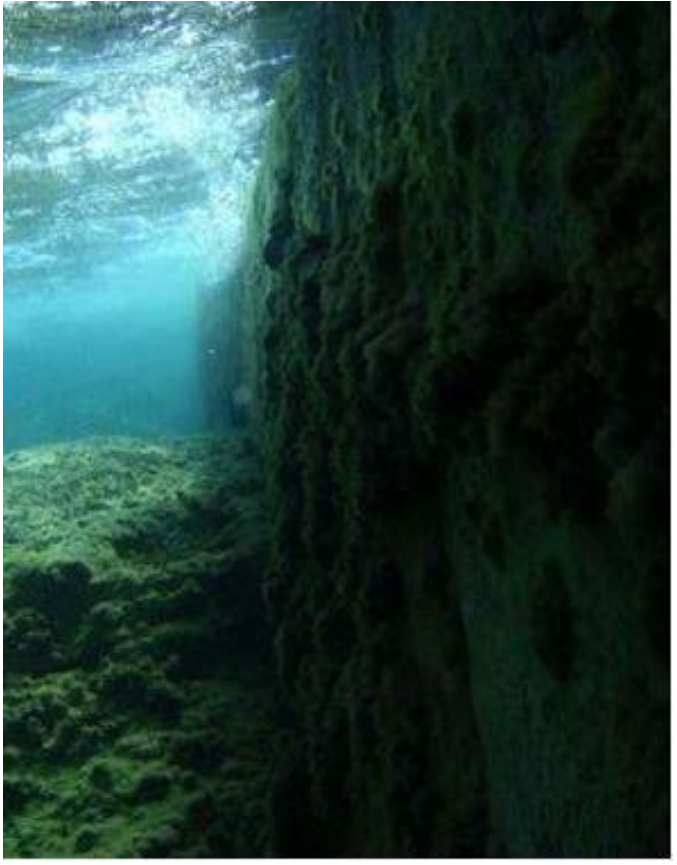

Fig 5. Western Facet

It were equally effective in the surrounding regions as well IX magnitude earthquake occurring on the island of Kos in 1493 caused great devastation in Bodrum Peninsula. In the Ottoman Period, VI-IX magnitude earthquakes occurred in 1741, 1851, 1863 and 1869, 1886 years. Ergin-Güçlü 1967: 189; Dirik et al. 2003: 29-30. 34 earthquakes had been in the collapse system of the Aegean. These earthquakes are an indication of the effect of fault lines that are still active in the area (Polat et al. 2008: 593614).

There are sarcophaguses which are at the depth of 4 meter and which were made from Koyunbaba stone in the western front of the dock (Fig. 8-9). These sarcophaguses must have fallen while loading to the ships. The antiques similar to these sarcophaguses, which were made stones, removed Koyunbaba Ancient Stone Quarries are exhibited in Underwater Archaeology Museum of Bodrum. As mentioned above, thanks to its characteristic which can easily shape and the original beauty of green color, there are block stones brought from stone quarry in many ancient settlement located in the Bodrum Peninsula (Bean-Cook 1955: 169 ff.), especially Mausolleion of Halicarnassos and the ancient city of Myndos 
(Bean-Cook 1955: 169 ff.; Tirpan 1988: 168 ff.; Ulusoya et al. 2004, 74; Şahin 2005, 174 ff.; 2006: 293 ff.).

However it is seen that Koyunbaba stones we encounter frequently in the ancient city of Myndos in the south about 2.5-3 km of this stone quarry are not used in the harbour structures. This situation results from the property of Koyunbaba stone. As mentioned above, the Formation of Koyunbaba consists of the alternations of yellow bronze, thin, smooth sandstone, marl-clay stone layer and there are the sandstone tubers in some places (Ercan et al. 1981: 26; Ulusoya et al. 2004: 74). Sandstone and clay pavers are easy to shape but not water-resistant. The most beautiful examples of this interaction are seen in the
West harbour of the Ancient City of Myndos. Although lower parts of the walls of the structure within the port made of hard limestone (Brinkmann 1967: 12). Koyunbaba stone is used in the upper parts (Fig. 10-11).

It is seen that waves don't damage cut block stones made of hard limestone on the lower parts of the walls, yet give harms to block tones made of Koyunbaba stone on upper parts and the forms of these block stones are damaged (Fig. 12-13). Being aware of this damage, Myndos people are seen to have used this Koyunbaba stone for the several structures such as fortification wall (Şahin 2005: 174), bath (Şahin et al. 2006: 563) and theatre that may be less affected by the water except for harbour structures (breakwater, jetty, etc.).

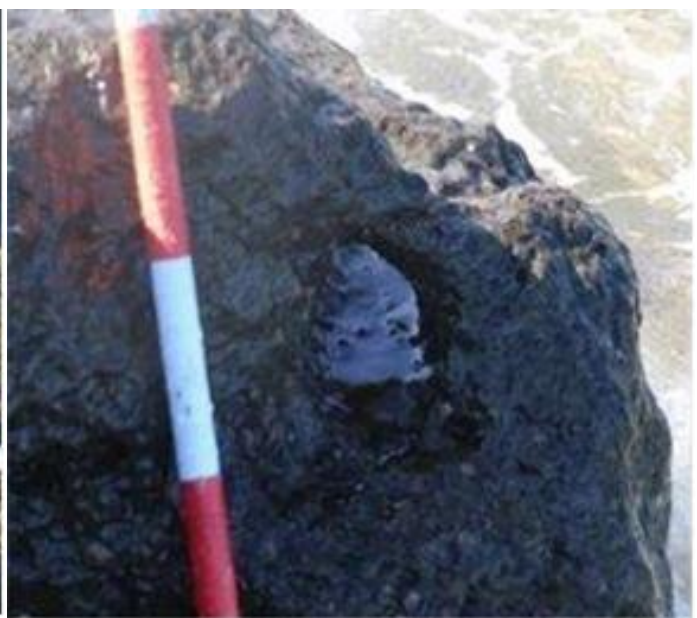

Fig 6-7. Examples of Mooring Holes. 


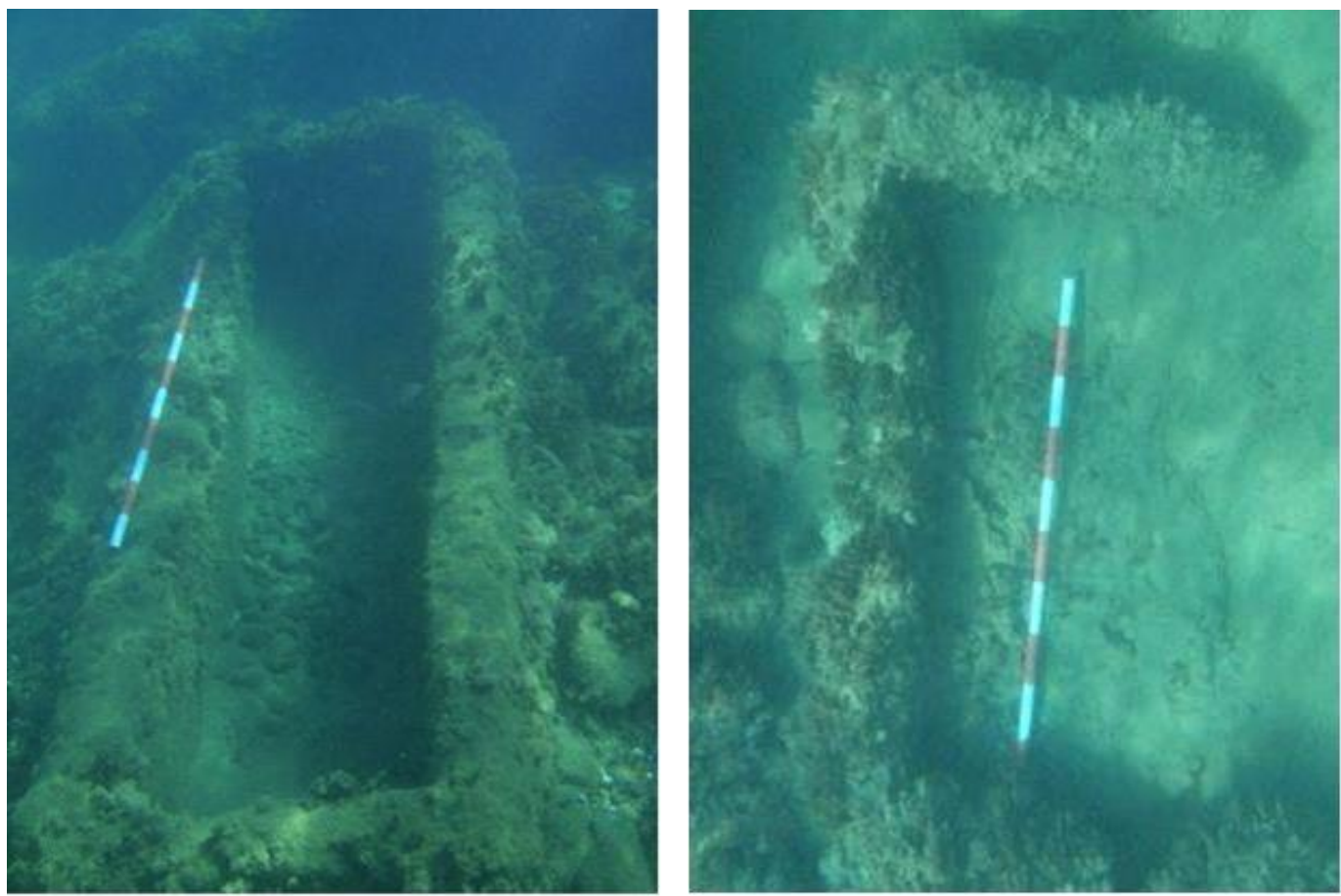

Fig 8-9. View of the Sarcophaguses in the 4-meter depth on South Facet of the Dock.
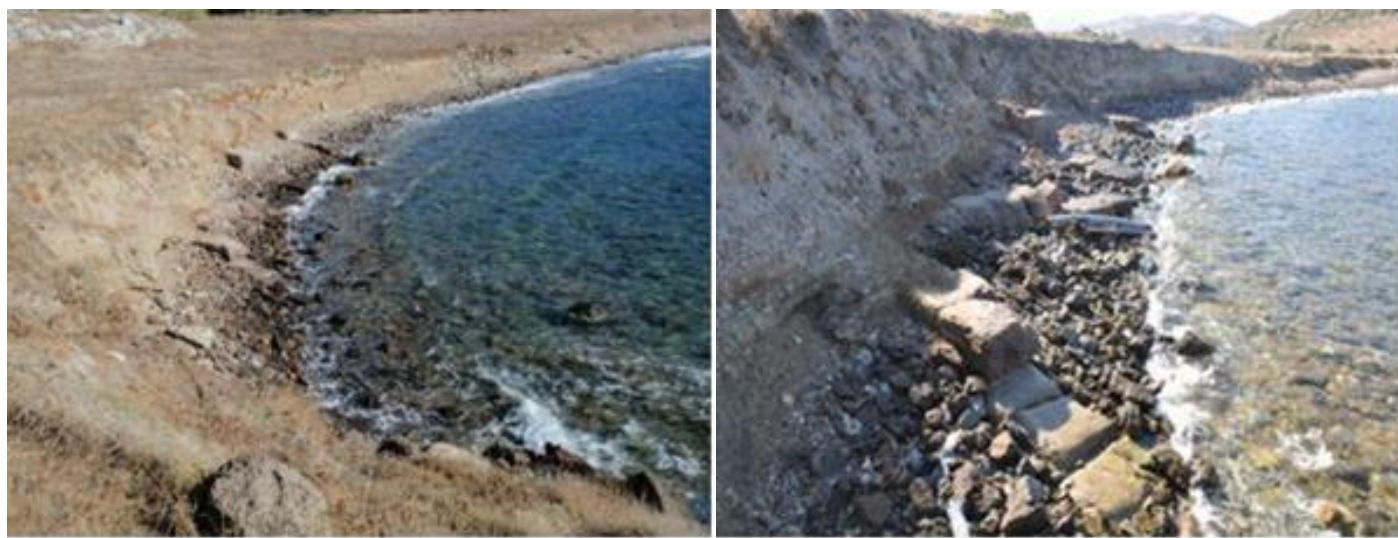

Fig 10-11. West Harbour of Myndos Ancient City - Views of Structure Ruins made of Koyunbaba and hard Lime Stone. 

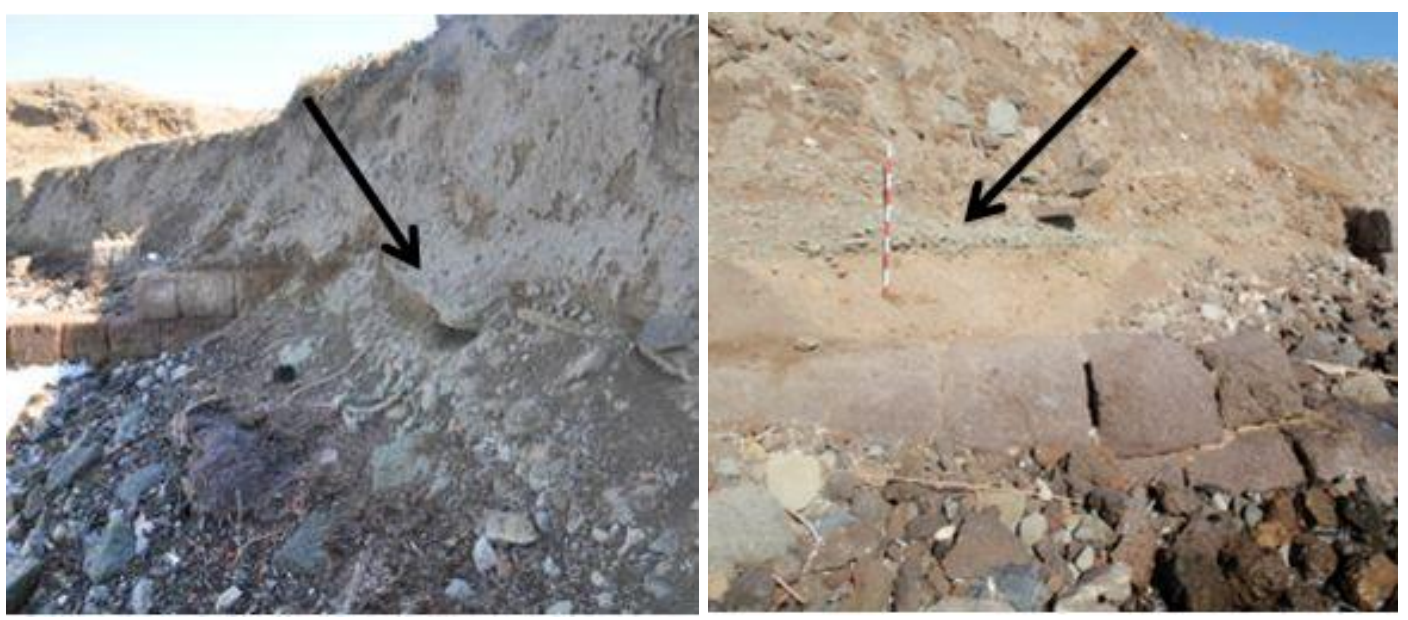

Fig 12-13. West Harbour in the Ancient City of Myndos- Views from the Ground made of Koyunbaba Stone.

\section{Conclusions}

Consequently, the ancient dock must be concurrent with history of use of Koyunbaba Ancient Stone Quarry. This type of structure is difficult to date and the archaeological data, historical sources that will support to the dating are taken into account. The archaeological data that will support on the dating are the famous Mausolleion and Myndos Ancient City's fortification walls in the ancient city of Halicarnassus. The ancient authors who will support about the dating are Strabon (Strab, Geog. XIV.2.16) and Vitruvius (Vitr., De arch.II.8.11) Either author provides information on the Mausolleion.

It is known to be used the stones brought from Koyunbaba Ancient Quarry (Bean-Cook 1955: 169 ff.; Hornblower 1982: 6, 264; Ulusoya et al. 2004: 74; Şahin 2005: 174 ff.; 2006: 293 ff.) in the construction of this monument started to be built by his wife Artemisia after the death of the Persian Satrap Mausollos and (Mausolleion)

\section{References}

Aslan, E. 2010. "Kekova Bölgesi Liman Araştırmaları 2009: Aperlai Limanı", ANMED,181 188.

Aslan, E. 2011. Kekova Bölgesi Limanları, Yayınlanmamış Doktora Tezi, Konya.

Bean, G. E. 2000. Eski Çağda Menderes Ötesi, P. Kurtoğlu (Çev), Arion Yayın Evi, İstanbul. constructed between 355-340 BC (Strabon, XIV.2.16; Hornblower 1982: 223-275; Ruzicka 1992: 103-104; Bean 2000: 99; Sevin 2001: 123). Furthermore, pursuant to (Synoikismos Policy) after Mausollos made Halicarnassos the capital (373-353 BC) combined 6 of 8 Leleg cities, left as Syangela and Myndos Ancient Cities and reconstructed (Strabon XII.159; Bean-Cook 1955: 96 ff; Radt 1970: 17 ff.; Mc Nicholl 1997: 23; Karlsson 1994: 144-153; Çimen 2004: 32; Bean 2000: 112). These include the construction of fortifications in construction work and it is seen that there are the block stones which were made from Koyunbaba stones from place to place in the ancient city of Myndos.

In this case, during the Hekatomnid dynasty, when we consider that block stones brought from Koyunbaba Ancient Stone Quarry are used in the structures whose dates are known with certainty, it is highly possible that Koyunbaba Ancient Stone Quarry dock is built in Classical period.

Bean, G. E. And Cook, J. M. 1955. "The Halicarnassus Peninsula", The Annual of the British School at Athens, Vol. 50, 85171.

Bekaroğlu, E. 2008. "Doğu Akdeniz'de Geç Holosen' de Yükselmiș Kıyı Çizgileri Üzerine Bir Değerlendirme", Coğrafi Bilimler Dergisi 6.1, 1-21. 
Blackman, D. J. 1982a. "Ancient Harbours in the Mediterranean Part 1", IJNA 11.2, 79104.

Blackman, D. J. 1982a." Ancient Harbours in the Mediterranean Part 2", IJNA 11.3, 185221.

Blackman, D. J. 2008. "Sea Transport, Part 2: Harbors", The Oxford Handbook Engineering and Technology in the Calassical World J. P. Oleson (Ed.), Oxford, 638-677.

Brinkmann, R. 1967. "Die Südflanke des Menderes massivs bei Milas, Bodrum und Ören", Ege Üniversitesi Fen Fakültesi İlmi Raporları, Seri, 43, 12-19.

Bruno, V. J. 1973. "An Ancient Roman Port in the Archipelago Toscano", IJNA 2.2, 365369.

Büyüközer, A. 2012. Knidos Limanları, Yayınlanmamış Doktora Tezi, Selçuk Üniversitesi, Selçuk Üniversitesi, Konya.

Çimen, L. 2004. Halikarnassos Yarımadası Şehir Surları, Yayınlanmamış Yüksek Lisans Tezi, Pamukkale Üniversitesi, Muğla.

Dirik, K., Türkmenoğlu, A.,Tuna N. And Dirican, M. 2003. Datça Yarımadası'nın Neotektoniği, Jeomorfolojisi ve Bunların Eski Medeniyetlerin Yerleşimi ve Gelişimi Üzerindeki Etkisi, ODTÜ AFP-00-07-03-13 Kod Numaralı Proje, Ankara.

Ercan, T., E. Günay and Türkecan, A. 1981. "Bodrum Yarımadasının Jeolojisi", Maden Tetkik ve Arama Dergisi, Sayı 97-98, 2132.

Ergin, S. And Güçlü, K. 1967. "A Catalogue of Earthquakes for Turkey and Surrounding Area", İstanbul Technic University Mining Faculty Journal 24, 169-189.

Flemming, N. C. 1978. "Holocene Eustatic Changes and Coastal Tectonics in the Northeast Mediterranean: Implications for Models of Crustal Consumption", Philosophical Transactions of the Royal Society of London, Series A, Mathematical and Physical Sciences, Vol. 289, No. 1362, 405-458.

Frost, H. 1973. "The Offshore Island Harbour at Sidon and Other Phoenician Sites in the Light of New Dating Evidence", IJNA, 2/1, 75-94.
Guidoboni, E., Comastri, A. and Traina, G. 1994. Catalogue of ancient earthquakes in the Mediterranean area up to the 10th century, Bologna.

Hornblower, S. 1982. Mausolus, Clarendon Press, Oxford.

Karlsson, L.1994. "Thoughts About Fortifications in Caria From Maussollos to Demetrios Poliorketes", Fortifications et Défense du Territoire en Asie Mineure Occidentale et Méridionale, P. Debord and R. Descat (Ed.), Bordeaux, 141-154.

Kelletat, D.1991. "The 1550 BP Tectonic Event in the Eastern Mediterranean as a Basis for Bssessing the İntensity of Shore Precesses", Zeitschrift für Geomorphologie, Supplementbande, 81, 181-194.

Mc Nicholl, A. W.1997. Hellenistic Fortifications From the Aegean to The Euphrates.

Polat, O., Gök, E. And Y1lmaz, D. 2008. Earthquake Hazard of the Aegean Extension Region (West Turkey), Turkish Journal of Earth Sciences, Vol. 17, 593-614.

Raban, A. 2009. The Harbour of Sebastos (Caesarea Maritima) in its Roman Mediterranean Context, M. Artzy, B. Goodman, Z. Gal (Ed.), BAR, International Series 1930, Oxford.

Radt, W. 1970. Siedlungen und Bauten auf der Halbinsel Von Halikarnassos unter besonderer Berücksichtigung der archaischen Epoche, Istanbuler Mitteilungen Beiheft 3, Tübingen.

Ruzicka, S. 1992. Politics of a Persian dynasty: The Hecatomnids in the fourth century BC., University of Oklohama.

Şahin, M. 2005. "Myndos 2004 yılı Yüzey Araştırması", Araştırma Sonuçları Toplantıs1, Sayı 23, Cilt 1, Ankara, 171184.

Şahin, M. 2006. "Myndos 2005 yılı Yüzey Araştırması", Araştırma Sonuçları Toplantıs1, Sayı 24, Cilt 1, Ankara, 293306.

Şahin, M., Sahin, D., Arslan, E. And Gündüz, S. 2006. "2005 Y1l Myndos Kazısı", 28. Kazı Sonuçları Toplantıs1, 559-572.

Sevin, V. 2001. Anadolu'nun Tarihi Coğrafyası, T.T.K., Ankara. 
Strabon, Antik Anadolu Coğrafyası

(Geographika), A. Pekman (Çev.), Arkeoloji ve Sanat Yayınları, 2000, İstanbul.

Testaguzza, 1970. Portus. Rome.

Tirpan, A. A. 1988. "Myndos ve Theangela", Araştırma Sonuçları Toplantısı 5, 167-190.

Ulusoya, İ., Cubukcu, E., Aydara, E., Labazuy, P., Gourgaud, A. And Vincent, P.M. 2004. "Volcanic and Deformation History of the Bodrum Resurgent Caldera System (Southwestern Turkey)", Journal of Volcanology and Geothermal Research 136, 71-96.

Vitruvius, Mimarlık Üzerine On Kitap, (Çev. Suna Güven), Yem Yayınları, 2005, İstanbul.

Williams, P. F. C.1976. "Roman Harbours", IJNA 5.1, 73-79. 